tions, for the repair of vesical fistula, but the round needle threaded with dry catgut, of the largest size which will follow the needle, has proved best; as the catgut swells and fills the needle track, cuts less, and appears better borne by the tissues.

It is necessary to remember that gentle handling of the tissue to avoid edema, elimination of scars, care in regulating the tension of sutures, and accurate approximation of the parts without undue strain are the chief points upon which success depends.

\section{MUCOUS CANCER OF THE BLADDER.*}

BY A. L. ChUte, M.D., AND A. H. CROSBIE, M.D., BOSton.

\section{CLINICAL REPORT.}

BY DR. A. L. CHUTE.

ON Sept. 22, 1911, I saw the subject of this paper a man 39 years old, who gave the following history:

Measles as a child. For some years "nervous indigestion" for which he had been very carefully studied and no physical basis demonstrated. Had been better of late.

In February, 1911, he passed a little bloody material in his urine. It was thought it might indicate a stone in his bladder and a radiograph was taken. This was negative.

In May, 1911, some discomfort referred to his bladder, noticed especially when he was on his feet a good deal. On July 6th frequent urination accompanied by clots, passed clots five times on this occasion, as much as one-half pint each time. Ten days later passed blood once more. Rested and had expectant treatment till last of July, when he began to go to business occasionally.

Early in September he began to pass small clots occasionally or little blood stained bits of tissue; one urination would be clear, the next bloody. Also had a little pain on urination now and again.

The patient was one of the most nervous individuals I have ever seen. Examination of his prostate, loins and reflexes was negative. Urine transparent; specific gravity 1023; no albumin; no sugar; urea $1.77 \%$. Bladder would hold a fair amount of fluid A cystoscope was passed and showed nothing abnormal in the lower segment of his bladder. Near the vertex of the bladder, and a little nearer the right than the left, there was a mass that appeared as large as a quarter. The center was necrotic and the edges more or less finely branched. It did not have the typical appearance of an infiltrating bladder growth, nor on the other hand was it typically papillomatous; it was suspicious enough so that early operation was strongly advised.

On October 5, 1911, with the help of Drs. O'Nei and Crosbie, I cut down on this patient's bladder. I started with the intention of making an extraperitoneal resection. When I had gotten the bladder well exposed extraperitoneally, I opened it and could feel near the vertex a very suspiciously hard mass the size of a large plum. The peritoneum was adherent to the bladder at this point so that extraperitoneal resection was out of the question. The * Read before the New England Branch of The American Urological Association, March 5. peritoneum was opened and the adherent part of it excised with bladder wall. The mass removed was about $2 \frac{1}{2}$ inches by $1 \frac{1}{2}$ inches, and in the fresh specimen gave a fair margin of normal mucous membrane on all sides. The bladder was sewed up in three layers. A drain was carried down behind the bladder and a retention catheter placed in the urethra.

In this case I did not put a suprapubic drain into the bladder. It would have been wiser to have done so, for on the sixth day the catheter became obstructed and there was some leakage along the wick that had been carried down to the posterior cul-de-sac.

This patient made a slow recovery, finally healed and left the hospital the latter part of November.

He went back to his business and was fairly active for a time. A few weeks ago he began to have pain, frequency and a somewhat turbid urine. For a time bladder washings relieved him. A few days ago his physician told me that he had a temperature, with pain referred to his left loin, also tenderness there. There also appeared recently a vague induration in the suprapubic region. There have been found in the urine a number of large cells showing a division of the nucleus. It seems reasonably certain that this patient has a recurrence of his growth that is already extensive enough to interfere with the left ureter.

[Oct., 1912. This patient shows a definite recurrence of his growth involving both bladder and abdominal viscera.]

\section{PATHOLOGICAL REPORT AND LITERATURE.}

BY DR. A. H. CROSBIE.

The subject of mucous cancer was brought to my attention by a pathological specimen sent to me by Dr. Chute for examination.

Examination of the tumor showed a firm mass, weight 50 grams, measuring 5 by 7 by $2 \frac{1}{2} \mathrm{~cm}$., with a border of $1 \mathrm{~cm}$. of normal bladder wall. The tumor was elevated both on the peritoneal and inner side of the bladder wall. On the inner surface there was an ulcerated area 3 by $4 \mathrm{~cm}$. in diameter. On section the mass was semitranslucent and of a gelatinous character.

Microscopical examination showed the whole tumor mass to be made up of nests of cylindrical goblet cells arranged in alveoli. These epithelial cells had infiltrated the whole bladder wall from the mucous membrane to the peritoneum. The alveoli were filled with mucus and there was a great deal of mucus all through the surrounding tissue. Frequently alveoli were seen, such as the one in the photograph presented, which had ruptured and poured out the mucus into the surrounding tissue. In the low power photograph one may see a large ruptured alveolus pouring out its mucus while close by is a group of small alveoli presenting a much more malignant appearance. The high power photograph shows that the cells are goblet or mucous cells.

In this case the cancer looks identical with those found in the rectum. The mucous cells, their adenomatous nature and all is exactly such as one would expect to find in the rectum. This form of cancer as a rule is very malignant.

The term mucous cancer is applied to a group of carcinomata in which there is a production 
of mucus formed either from the epithelial or from the stroma. Other terms used are gelatinous, and colloid cancer. Colloid is not good as the substance found in these cancers is not true colloid but does give the reactions for mucin. Delafield and Pruden say that "The cells of certain carcinomata, especially those of the gastrointestinal tract may develop a translucent gelatinous material which accumulates within the cells. These tumors often present an alveolar structure with the lumina of the alveoli filled with mucus which the cells have secreted. The mucus can be seen in the protoplasm of the cells as large translucent droplets. The mucus is usually pushed to one extremity of the cells. The cells of this type are as a rule cylindrical. The droplets are seen in the end of the cell protruding into the alveoli." In this description Delafield and Pruden are apparently describing the ordinary mucous cancer of the intestinal tract. No mention is made of another type of which I will speak later.

Of these tumors Bland Sutton says, "The commonest form of degeneration in cancer is known by the meaningless term of colloid degeneration. The epithelium in the cell column becomes changed into a structureless material resembling jelly. In many situations, particularly the stomach and the breast, this change is prone to occur."

Ziegler says of these: "The production of mucus in carcinomata occurs especially in the gastrointestinal tract. The mucous products first collect in the lumina of the alveoli after the manner of gland secretion. Later the border cells surrounding the mucoid material are broken through and the mucus is pushed out, forcing itself through the surrounding tissue. In many cases after an alveolus has thus been ruptured the epithelial cells disintegrate, leaving only the mucus. This type is to be distinguished from the carcinoma myxomatosum in which the myxomatous degeneration of the connective tissue cells between the cancer nests."

The only place that I can find record of these cancers occurring is in the breast, in the intestinal tract and in the bladder wall. As most of these cancers are composed of goblet or true mucous cells we would expect to find them only in organs which have a mucous membrane containing mucous glands, as in the intestinal tract. In the breast there are no such glands and we would not expect mucous cancer. However, when we come to study the form of mucous cancer of the breast we find that it differs from the one found elsewhere.

In the breast the mucous cancer is the least malignant of the breast cancers. Cases frequently go several years without the formation of metastases. The character of the mucous cancer of the breast is decidedly different from the ones found in the intestinal tract and bladder. In the breast the epithelial cells apparently do not enter into the formation of the mucus. The mucus is formed by a degeneration of the stroma. There are nests of epithelial cells, surrounded by mucus and a little connective tissue. Frequently the epithelial cells are arranged in alveoli but the alveoli do not contain mucus. There is a tendency for the epithelial cells to disintegrate, probably due to lack of sufficient nourishment brought about by the presence of the surrounding mucus.

Dr. Whitney suggests that the epithelial cells in these cancers may produce a toxin which causes mucous degeneration of the stroma. The mucus in turn reacts on the cells by cutting off their nourishment and thus inhibiting their growth.

The mucous cancers found in the intestinal tract are usually different from the ones in the breast. In these the epithelial cells themselves produce the mucus. Occasionally the same type is found here that is found in the breast. As a rule the epithelial cells are arranged in alveoli and the cells are cylindrical goblet cells filled with mucus with the nucleus pushed to one end, the end away from the lumen of the alveolus. Frequently these alveoli burst and the mucus is pushed out through the surrounding tissue. Often after the mucus has passed out and surrounded the alveolus the cells disintegrate, leaving nothing in places but the mucus. The mucous cancers of the intestinal tract are much more malignant than the ones in the breast and do tend to metastasise. This is especially true of the ones in the rectum, which is a frequent seat for these tumors.

Strange to say, the urinary bladder, which is supposed to contain no mucous glands, is occasionally the seat of primary mucous cancer.

There are a few similar cases reported in literature, mostly by Germans.

Rosenbusch had a case that came to him with a history of hematuria for ten months. She died soon after of pulmonary embolus. The tumor here was the size of the fist, situated in the posterior wall of the bladder. The bladder was adherent to the uterus and to the intestines. There was extensive ulceration of the mucous membrane over the tumor. Nearly all of the bladder wall was infiltrated and thickened with the mucous containing tissue. They were extensive metastases in the retroperitoneal lymph nodes. Microscopical examination showed the tumor to be made up of masses of epithelial cel's, many forming alveoli and in all stages of mucous degeneration. The alveoli were filled with mucus and sometimes with masses of degenerated epithelial cells. The connective tissue and muscle between the epithelial masses was infiltrated with free mucus.

Sharp reports a case of primary colloid carcinoma of the bladder in which the whole bladder wall was thickened and had a semitranslucent appearance on section. Microscopically the submucous tissue and nearly the whole thickness of the muscular coat was infiltrated with colloid material arranged in alveoli. In a few of the alveoli the bloated outline of the original cells 
could be discerned. Most of the mucous membrane had been removed by ulceration. Nearly the whole bladder wall was thickened and the lumen was much reduced.

We meet with a similar case reported by Sauter. In his the disease had lasted two years. The whole bladder wall was thickened by colloid cancer.

In 1883 Sperling reports a case of primary mucous cancer of the bladder involving the uterus and vagina. The nature of the epithelial cells is not given.

Ehrich had a woman 44 years old who had extrophy of the bladder which was involved with mucous cancer. The epithelial cells here were cylindrical goblet cells forming alveoli which were filled with mucus.

Posner in 1883 had a patient 46 years old with a mucus cancer on the posterior wall of the bladder the size of an orange. The nature of the cells is not stated.

Stoerck reports one with a flat tumor size of a dollar arising from the trigon. The alveoli were filled with mucus and the cells were goblet cells. In some places the epithelial cells had entirely disappeared, leaving nothing behind but mucus.

Zausch reports two cases. One with a tumor in the right side of the bladder and showing no metastases, while in his other case there were retroperitoneal metastases.

Haake describes a mucous cancer in the fundus of the bladder of a man 72 years old. This case has a nodule of similar type in the prostate.

Rudolph Bayard reports one case in which the tumor corresponded closely to the rectal carcinoma.

Although most observers agree that there normally are no mucous glands in the bladder they do admit that frequently glands are found, especially in the neck of the bladder near the urethra. Some hold that these are strayed urethral glands while others think that they are aberrant prostatic glands.

In determining why mucous cancer should appear in the bladder it strikes me there are three possibilities to be considered. They may arise from the strayed urethral glands, from the aberrant prostatic glands, or from a faulty embryological development.

In describing the develpoment of the bladder in the embryo Piersol says, "During the early life of the human embryo the end segment of the gut is dilated into an elongated chamber, the cloaca, from the upper end of which the alantois passes forward and on the sides of which open the Wolffian ducts. The dilated alantosis forms the body and summit of the bladder and the urachus, the lower end of the'bladder into which the ureters open, is derived from both the alantosis and from the cloaca."

It is easy to understand therefore how cells which should properly form rectal mucous membrane might become cut off and lodged in the bladder wall. When these cells becorre rancerous one may see why they should retain the characteristics of the cells of the rectal mucous membrane.

I wish to express my thanks to Dr. William F. Whitney and to Dr. Arthur L. Chute for their helpful suggestions.

1 Aschoff, Dr. L. Ein Bitrerature.

L. Ein Beitrag, zur normalen und pathologischen Anatomie der Harnwege und ihrer drïsigen Anhänge. Arch. $f$.

Path. Anat. Bd. 138, S. 119.

2 Broesicke, Dr. Gustav, Lehrbuch der normalen Anatomie. 6. Aufl., 1899.

3 Delafteld and Pruden.

4 Ehrich, Dr. E., Gallertkrebs der ekstrophierten Harnblase. Beiträge zur klinischen Chirurgie. P. v. Brunns. Bd. 30, 1901. S. 581.

'Haake, Otto, Uber den primären Krebs der Harnblase. Inaug.-

Diss. Freiburg i. Br., 1895.

'Lubarsch, Archiv' für milroskopische Anatomie, Bd. 41, S. 303. Piersol, Human Anatomy.

8 Posner, Ein Fall von primarem Karzinom der Hasnblase. Berliner kliniscre Wochenschrift, 1883 , s. 392.

8 Rosenbusch, Arch. f. Path. Anat., clxxxii.

10 Rudolph Bayard, Vir. Arch., v. 196.

11 Saunter, Richard, Ein Fall von Gallertkarzinom der HarnBlase, Inaug.-Diss. Munchen, 1898.

13 Sharp, H. C., Primary Colloid Carcinoma of Bladder. Path. oc. of London, March 5, 1896.

${ }^{13}$ Stoerck, O., Beiträge zur Pathologie der Schleimhaut der arnleitenden Wege. Ziegler's Beiträge, Bd. 26, S. 367.

${ }^{14}$ Stöhr, Text-book of Histology.

15 Zausch, Karl, Zur Statistik des Carcinoma vesicae, Inaug.Diss. Munchen, 1887 .

16. Ziegler, Prof. E., Lehrbuch der allgemeinen Pathologie. 10 Auflage, 1901 .

\section{Reprorta of Soriptipg.}

\section{AMERICAN UROLOGICAL ASSOCIATION.}

Mid-Winter Meeting of the New England Branch, Boston Medical Library, March 5, 1912 ; And Spring Meeting, Boston, May 21, 1912.

President, Dr. Paul Thorndike, Boston. Secretary, Dr. R. F. O'NeIL, Boston.

PRESENTATION OF INSTRUMENTS, DR. E. GARCEAU.

\section{SOME NEW CYSTOSCOPES AND A URETER CATHETER} FOR COLLECTING THE TOTAL OUTPUT OF URINE FROM ONE KIDNEY.

Dr. GarceaU: The instruments which I am showing tonight were devised to collect the total output of urine from each kidney during an examination to test the work of each.

The catheters heretofore employed for this purpose have not been satisfactory. Those with bulbous enlargements at the ureteral end do not always succeed in entering the canal and they do not always completely block it even when they do enter it. Those having the small inflatable rubber balloon at the ureteral end which can be inflated after the catheter is in position are open to the objection that the rubber soon deteriorates. The commonest method has been to pass with a cystoscope two No. 8 French catheters, one on each side, and to trust there will be no leakage alongside the instruments. Leakage is detected by means of a catheter laid in the bladder. Larger double cystoscopes which might take larger catheters are not feasible on account of their size. With a No. 8 French catheter in each ureter leakage alongside the instruments occurs in 48 per cent. of the cases. It amounts to 20 cubic centimeters or less, in 21 per cent.; 20 to 50 cubic 